\title{
Environmental Damage and Overpopulation: Demographic Aspects
}

Keywords: Population; Birth rate; Demography; Gender imbalance: Reproductive coercion; International conflicts

\section{Abstract}

Environmental damage is proportional to the population density. The overpopulation leads to a shortage of fresh water and food in many regions. Smoldering international conflicts provide motives for the population growth. The necessity of birth control has been obfuscated by conflicting national and global interests, the population growth being regarded as a tool helping to the sovereignty and national defense. Several regions with a relative overpopulation, actual or potential conflicts are discussed here. Today, when common interests of the humankind are becoming obvious, the introduction of new moral principles is needed. One of such principles is that a birth rate of an ethnic minority should not be higher than that of the main nation of a country. Social consequences of gender imbalance must be borne mainly by those population groups, where sex-selective abortions are practiced. Recognition of these principles can become a basis for the international trust and cooperation.

\section{Introduction}

All kinds of environmental damage are proportional to the population density [1]. The overpopulation is a principal reason for the shortage of fresh water and food. In the last quarter of the 20th century, population grew faster in developing than in highincome countries, while, compared to the population growth, an increase in carbon emissions grew faster in developing countries than in high-income ones [2]. In the past, overpopulation has been reduced by homicide, epidemics and starvation. Today, there is a possibility to apply humane, scientifically based methods, consciously choosing between the birth rate restriction and mortality rise. Surgical sterilization is the most reliable method of birth control; it was applied in India in the 1970s, but later these measures have been rolled back. The one-child policy in China was successful, but has been dismantled. Appeals can be hard to completely abolish the family planning and birth control in China [3].

Countries receiving immigrants decide whom they admit and whom not. Sterilization can be taken into account making decisions about residence and work permits. The male sterilization (vasectomy) is a simple and harmless procedure. The female sterilization (tubal ligation) can be performed without additional trauma at a birth by cesarean section. A more frequent use of cesarean tubal ligation would be especially favorable for overpopulated regions with a gender imbalance [4]. Certainly, surgical sterilization can be seen as a violation of the bodily integrity. The same, however, can be said about sexual and reproductive coercion sometimes committed for migration/accommodation purposes or to spread a certain genotype, with conscious or subconscious geopolitical motives (discussed below).
Journal of

Environmental Studies

\author{
Jargin SV* \\ Department of Pathology, People's Friendship University of Russia, Russian \\ Federation, Russia \\ *Address for Correspondence \\ Jargin SV, Department of Pathology, People's Friendship University of \\ Russia, Clementovski per 6-82, 115184 Moscow, Russia, Tel: 7495 \\ 9516788; E-mail: sjargin@mail.ru \\ Submission: 26 August, 2021 \\ Accepted: 28 September 2021 \\ Published: 05 October 2021 \\ Copyright: $\odot 2021$ Jargin SV. This is an open access article distributed \\ under the Creative Commons Attribution License, which permits \\ unrestricted use, distribution, and reproduction in any medium, provided \\ the original work is properly cited.
}

\section{Overpopulation and gender imbalance}

Logically, rapidly growing population groups should live in less spacious conditions. Consequences of the gender imbalance must be borne by the populations with imbalance due to immigration and/ or sex-selective abortions. The recognition of these principles can become a basis for the international understanding and trust. In consideration of ecological and economic conditions, an optimal fertility level should be recommended for different regions. Who will determine the level? Primarily, everybody, for her or himself. In a country with sufficient water resources, the birth rate of the main nation can be higher than in a desert, where inhabitants consume desalinated water and foodstuff acquired for the foreign aid and/or oil revenues. An international organization could issue evidence-based recommendations [5].

Among the mechanisms leading to the gender imbalance are sexselective abortions [6]. In accordance with traditions, economical and social motives, many families prefer to have sons. A gender imbalance among the newborn has been reported from China, India and some neighboring countries, from the Caucasus as well as the immigrant milieu in the United States and Europe [7-9]. Migrations contribute to the gender imbalance: the shortage of males creates additional motives for sex-selective abortions in the emigration countries. In Russia, considerable gender imbalance is observed among immigrants. According to the 2014 census, the male/female ratio in the Crimea, among ethnic Russians was 0.85, Tatars - 0.98, Armenians - 1.3, Karaites - 1.3, Krymchaks - 1.4 [10]. The following male/female ratios among newborns were reported for the period 2015-2020: Azerbaijan - 113, China - 113, Armenia - 111, India 110, Albania - 109 [11]. Evaluating statistics, it should be taken into account that the gender imbalance is veiled by shorter life duration of males. In the Russian Federation, the imbalance with predominance of men of working ages is superseded by prevail of women in the retirement age [12]. Obviously, the social significance of gender imbalance is decreasing with age. Official statistics based on censes tend to underestimate the gender imbalance as predominantly males are involved in migrations, some of them remaining uncounted by censes. Social programs supporting families with girls are supposed 
to be expensive and difficult to implement [11]. Prohibitive measures against sex-selective abortions may be not sufficiently effective as they would stimulate such "traditional" methods of demographic control as female neonaticide and neglect of newborn girls $[6,13,14]$. The predominance of males is more conspicuous in lower socio-economic classes; their marginalization may lead to antisocial behavior. As the excess of men may cause insecurity, families would be further motivated to have sons for protection. The growing excess of men may contribute to militarism and international conflicts. Furthermore, a mechanism maintaining the highest birth rate and son preference is related to the insufficient public assistance. Ageing people depend on their children for support, while sons and their families are supposed to be better caregivers than daughters at least in some cultures [15]. An improvement of the social security in developing countries must positively influence the demographic processes.

\section{Ethnic transformations}

In the past, the high birth rate was used to support national independence. Even today, a large population is sometimes seen as a guarantee of sovereignty. Birth rate inequalities result in minorities becoming majorities, which can cause local conflicts. An example is Kosovo, where the Albanian majority developed as a result of the immigration and higher birth rate [16,17]. Similarly to ethnic Russians in some parts of the former Soviet Union (fSU), Serbs are leaving Kosovo. Within fSU, the most significant changes have been observed in the Caucasus and Central Asia. The emigration of ethnic Russians from these regions started several decades ago and increased after the dissolution of the fSU. The immigration to Russia from Central Asia is growing. In the North Caucasus, absolute numbers and percentages of ethnic Russians are decreasing both in urban and rural areas. The maximal birth rates in the Russian Federation have been recorded in Ingushetia, Chechnya, Tuva and Dagestan; while the population is decreasing most rapidly in Tambov, Tver, Tula and Pskov provinces [18]. There is a continuous migration of Chechens from the mountainous to plain areas to the North of the Caucasian Mountains. Per capita incomes in the North Caucasus lag behind the population growth [19]. The Armenian minority is growing in Stavropol and Krasnodar provinces, especially in the Caucasian Riviera (Black Sea coast), where they have massively participated in privatization and construction of houses [20]. In the above-named provinces, percentages of North-Caucasian ethnicities, Armenians and Romani people are growing while ethnic Russians are leaving [21]. Migration distances are increasing: from the Caucasus and Middle Asia to Moscow, Königsberg-Kaliningrad, Siberia and the Far East [22]. In all provinces of the Russian Far East (except Yakutia), the ethnic Russian population decreased during the period 20022010. Since 2000, migration to the Far East and Siberia from Central Asia and China has been increasing. During the period 2002-2010, the number of Tajiks in the Far East increased 2.3 times, Uzbeks 3.4, Kyrgyz - 3.8 times [23]. The population growth in the Russian Far East has been maximal in Buryatia and Yakutia (Sakha) Republics thanks to higher birth rates of the indigenous ethnic groups [24].

In this connection, the Jewish question must be briefly tackled. As discussed above, to prevent ethnic conflicts, minorities should not grow more rapidly than the main nation of a country. This is understood in many Jewish families. However, in the conservative milieu the birth rate remains relatively high. In some cities e.g. New York the Jewish population is considerable. After the World War II, people of Jewish descent had a possibility to lead a normal life almost everywhere. Evidently, a moderation in the birth rate has been advisable. The migration to the populated territory with a shortage of fresh water and energy resources occurred after individual decisions of the migrants. Since 1948, the population of Israel increased from 850 thousands to $>9$ million people [25]. The militarized society has deprived a part of the ex-Soviet intelligentsia of their hoped-for perspectives [26]. Each migrant to Palestine could realize that he or she was going, directly or indirectly, to take possession of other people's property and to live partly at the expenses of the foreign help, mainly from the United States and Germany. Moreover, the ethnic discrimination in the German immigration policy should be mentioned. It sufficed to declare oneself a Jew to obtain an unlimited residence permit and social assistance. In this way, other foreigners are discriminated: after many years of work they have to leave the country. Some refugees live for social benefits years-long. The welfare agency (Sozialamt) is regarded as a club for selected public, where the wealth is distributed: regular cash payments, apartments, medical and pension insurance, free education, etc. Conversations of this kind about Sozialamt can be heard in an upscale restaurant or a consular office, where these refugees are inviting to Germany their relatives and friends. Some refugees are engaged in more or less legal business evading taxes. Apartments paid by the Sozialamt are sometimes subleased. Despite legal and moral barriers, many refugees of this kind travel to their former homeland in the fSU. There are cases when the refugees rented out their Moscow apartments, or when a paterfamilias operated a business in Russia, while the family lived in Germany for the welfare benefits. The Camp David Accords have been an efficient tool to acquire foreign aid. Israel has been the largest cumulative recipient of the U.S. foreign assistance since the World War II [27]. After the Camp David Accords, American aid to Egypt increased considerably. Apparently, some former adversaries in the Middle-Eastern conflicts acted to the mutual benefit. There seems to be a more or less covert alliance between certain spheres on both sides, while the set of ideas, prevalent also in some other places of the Middle East, Caucasus and Central Asia, includes the high natality, migrations and, wherever tolerated, reproductive coercion [28]. A solution for Palestine, Syria and some adjacent territories could be a protectorate by developed nations with the aim to preserve as much human life and wealth as possible, to ensure equality and safety, to curb the population growth in the desert, stimulated by the long-lasting conflict [5]. The agricultural farming in conditions of insufficient fresh water and energy resources is environmentally unfriendly and economically disadvantageous as imported fossil fuels are burnt for the desalination. If peace in the Middle East would be guaranteed, the problem of the energy supply for water desalination could be largely solved by nuclear power plants. The foreign aid is currently wasted for military purposes. There are no alternatives to the nuclear energy today [29]. In the long run, non-renewable fossil fuels will become more expensive, contributing to the population growth in oil producing regions and poverty elsewhere. Nuclear power has come back to the agenda due to concerns about increasing global energy demand and climate changes. Health burdens are greatest for power stations based on coal and oil. The burdens are smaller for natural gas and still lower for nuclear power. The same ranking applies also to 
the greenhouse gas emissions and thus probably to climate changes [30]. Obviously, peace and international trust are needed for a safe development of the nuclear industry.

\section{Sexual and Reproductive Coercion}

Migrants are partly criminalized; in particular, sexual and reproductive coercion (RC) are known to occur, sometimes applied deliberately for migration purposes. Reportedly, about $70 \%$ of rapes in Moscow have been committed by immigrants from Central Asia [31]. Certain other minorities have been active as well. RC interferes with a woman's decision-making about reproduction; it may consist of contraception sabotage and/or pressure to carry a pregnancy to term. $\mathrm{RC}$ is not always understood as such by the victim; in particular, the intimate partner violence (IPV) may prevent a woman from naming certain behaviors as coercion; details and references are in [28]. In the author's opinion, the criminal justice should handle the neglectful and intentional contraception sabotage in and out of wedlock as a crime with infliction of bodily harm if an abortion or unintended pregnancy followed. Several case histories have been discussed in the preceding paper in connection with the topic of this article [28]. Certain cases were reported to the authorities after a delay as the denunciation of illegal and immoral acts was unusual in FSU, especially if committed by individuals from the privileged milieu. In some cultural settings with a rape myth acceptance, sexual violence has been a method of acquiring wives $[32,33]$. The fact that some victims married their rapists was erroneously seen as indication that women enjoy it; in fact, existing accounts demonstrate various degrees of trauma [33]. In this connection, it is important to detect the violent entrapment or "battered woman syndrome" including the learned helplessness [34,35]. Among potential contributing factors are the machismo ideology, disrespect for laws and regulations, impunity of some offenses and offenders. It should be mentioned that in certain ethnicsocial milieus boys may be instructed within their families. Sexual experiences with relatives are not unusual in chaotic environments [36]. It was reported that $49 \%$ of the "child perpetrators" had been sexually abused prior to their own abusive behaviors [37].

It can be reasonably assumed that the social progress would correlate with improvements of morality. However, international migrations confound this scheme, while the alcohol-related neglect of contraception gives way to migration-related and geopolitical motives [5]. The reproductive coercion is sometimes used to spread a certain genotype or to cement a marriage contracted to obtain a residence permit and/or lodging. The latter may be one of the mechanisms of birth rate elevation noticed immediately after immigration $[38,39]$. Cases are known when a potentially heritable disease (type 1 diabetes mellitus, male Stein-Leventhal, Marfan syndrome etc.) in a perpetrator was concealed from the partner and then acquired by offspring. Various methods are applied: seduction and persuasion up to hypnosis, alcohol and drugs, intimidation and IPV [28,40] Considering the forthcoming globalization, women should be aware of these strategies. As mentioned in the Introduction, sterilization may be a workable solution especially for males incapable or unwilling to control their behavior and consistently use condoms, although it does not prevent STI. Vasectomy is a safe and efficient method of permanent contraception, it is obviously preferable to abortion and unwanted pregnancy; details and references are in [28]. In regard to the tubal ligation, its combination with cesarean section (CS) i.e. cesarean tubal ligation should be considered by women not planning further pregnancies. In the author's opinion, CS on maternal request must be available in the absence of medical contraindications for vaginal delivery. In particular, this pertains to Russia, where CS is usually not performed on a maternal request [41]. Considering the global overpopulation, the worldwide increase in the CS rate is a favorable development especially in overpopulated regions [4].

\section{Discussion and Conclusion}

The workforce productivity is growing; few workers can provide a means of subsistence for many people while unemployment is growing. In the past, similar developments were interrupted by wars or pestilence. This has not happened long since; we are waiting to see what happens while the global population is increasing. However, there are many things to do. Great projects could be accomplished to improve the life of billions: irrigation facilities for droughtstricken lands, worldwide development of nuclear and other energy sources as alternatives to fossil hydrocarbons. Scientific research should be revitalized, purged of falsification and tendentiousness due to commercial interests or ideological bias [42]. Such efforts would create work for many people. The necessity of birth control has been obfuscated by conflicting national and global interests: the population growth has been seen as a tool helping the sovereignty and economic advance of developing countries. Smoldering conflicts provide further motivation for the population growth, in particular, in the regions with a shortage of fresh water and energy resources [5]. An international authority based in developed countries could counteract the growing overpopulation and environmental damage. Most importantly, people must learn to trust each other.

\section{References}

1. Guillebaud J (2016) Voluntary family planning to minimize and mitigate climate change. BMJ 353: i2102.

2. Cohen JE (2010) Population and climate change. Proc Am Philos Soc 154: 158-182.

3. Fan Lieming (2019) Will China's "Two-child in One Family" policy to spur population growth work? Population and Economics 3: 36-44.

4. Jargin SV (2018) Cesarean combined with tubal sterilization: some medical and demographic aspects. Rev Bras Saude Mater Infant 18: 677-679.

5. Jargin SV (2019) International conflicts and overpopulation. Current Politics and Economics of Northern and Western Asia 28.

6. Hesketh T, Min JM (2012) The effects of artificial gender imbalance. Science \& Society Series on Sex and Science. EMBO Rep 13: 487- 492.

7. Egan JF, Campbell WA, Chapman A et al (2011) Distortions of sex ratios at birth in the United States; evidence for prenatal gender selection. Prenat Diagn 31: 560-565.

8. Michael M, King L, Guo L et al. (2013) The mystery of missing female children in the Caucasus: an analysis of sex ratios by birth order. Int Perspect Sex Reprod Health 39: 97-102.

9. Singh N, Pripp AH, Brekke T, Stray-Pedersen B (2010) Different sex ratios of children born to Indian and Pakistani immigrants in Norway. BMC Pregnancy, Childbirth 10: 40.

10. Statistics of Russia (2015) Results of the Crimean Federal District Census, Moscow.

11. Sakevich V (2021) The problem of deranged gender ratio in the region, Eastern Europe and Central Asia. Demoscope Weekly 887-888. 
Citation: Jargin SV. Environmental Damage and Overpopulation: Demographic Aspects. J Environ Stud. 2021;7(1): 4.

\section{ISSN: $2471-4879$}

12. Dobrokhleb VG (2020) Demographic aging in the aspect of gender problems in modern Russia. Population (Moscow) 23: 5-13.

13. Baird V (2011) The no-nonsense guide to world population. New Internationalist Press, London.

14. Jargin SV (2018) The male to female ratio at birth: The role of femicide and other mechanisms. Early Hum Dev 123: 33-34.

15. Kadoya Y, Yin T (2012) Gender imbalance at birth and parents' anxiety about old age in China. Discussion paper No. 855. Osaka University.

16. Chiari B, Kesselring A (2006) Wegweiser zur Geschichte Kosovo. MGFA, Schöningh: Paderborn.

17. Reuter J, Clewing K. Der Kosovo Konflikt: Ursachen - Verlauf - Perspektiven. Wieser: Klagenfurt; 2000.

18. Arkhangelsky VN, Potanina YuA, Khasanova RR (2015) Regional differences in the natural population movement in Russia. Population (Moscow) 18: 68-78.

19. Panin AN (2018) Mapping the North Caucasus: demographic gradients and investment risks. Population and Economics 2: 121-142.

20. Riazantsev SV (2003) The demographic situation in the North Caucasus. Sociological Research 42: 230-244.

21. Shchuplenkov OV (2018) The Southern Stream (migration problems in the South of Russia), Etnosocium, Moscow (in Russian).

22. Pobedonostseva Elu, Svezhinskii EA, Kurbatova OL (1998) Geneticdemographic processes in the Moscow population in the mid 1990's. Analysis of ethnographic migration parameters (isolation by distance). Genetika 34: 423-430.

23. Motrich EL (2016) Demographic situation in the Russian Far East: the key trends and challenges. Population (Moscow) 19: 25-33.

24. Simagin Yu A, Murtuzalieva DD (2020) Demographic problems of geostrategic territories of the Russian Far East. Population (Moscow) 23: 153-160.

25. World news (2019) The population of Israel exceeded 9 million. Demoscope Weekly 813-814.

26. Biagioli M, Lépinay VA (2019) From Russia with code: programming migrations in post-Soviet times. Duke University Press, London.

27. Sharp JM (2018) U.S. Foreign Aid to Israel. Congressional Research Service.
28. Jargin SV (2021) Reproductive and sexual coercion: The role of alcohol, social and demographic conditions. J Addiction Prevention 9: 5.

29. Jargin SV (2019) The Overestimation of Medical Consequences of Low-Dose Exposure to lonizing Radiation. Cambridge Scholars Publishing, Newcastle upon Tyne.

30. Markandya A, Wilkinson P (2007) Electricity generation and health. Lancet 370: 979-990.

31. Streaming luA (2019) Determinants of crime by migrants in conditions of a Megapolis. In: Actual problems of migrations. Proceedings of an Interuniversity scientific and practical conference. Ministry of Internal Affairs of the Russian Federation, Domodedovo 73-76.

32. Renzetti CM, Edleson JL, Bergen RK (2012) Companion reader on violence against women. Sage, Los Angeles.

33. Russell DEH (1990) Rape in marriage. McMillan, New York.

34. Black A, Hodgetts D, King P (2020) Women's everyday resistance to intimate partner violence. Fem Psychol 30: 529-549.

35. Tolmie J, Smith, R, Short J, Wilson D, Sach J (2018) Social entrapment: A realistic understanding of the criminal offending of primary victims of intimate partner violence. New Zealand Law Review 2: 181-217.

36. Meiselman KC (1978) Incest: a psychological study of causes and effects with treatment recommendations. Jossey-Bass: San Francisco.

37. Johnson TC (1988) Child perpetrators - children who molest other children: preliminary findings. Child Abuse Negl 12: 219-229.

38. Kazenin KI (2018) Impact of migration on fertility: key hypotheses facing evidence from the North Caucasus. Population (Moscow) 21: 48-59.

39. Anderson G (2004) Childbearing after migration: fertility patterns of foreignborn women in Sweden. International Migration Review 38: 747-775.

40. Hoencamp E (1990) Sexual abuse and the abuse of hypnosis in the therapeutic relationship. Int J Clin Exp Hypn 38: 283-297.

41. Likhachev VK (2014) Operative obstetrics with a phantom course. MIA, Moscow (in Russian).

42. Jargin SV (2020) Misconduct in Medical Research and Practice. Nova Science Publishers. 